\title{
High tunnels for local food systems: Subsidies, equity, and profitability
}

\author{
Nathaniel Foust-Meyer ${ }^{a *}$ and Megan E. O'Rourke ${ }^{b}$ \\ Virginia Polytechnic Institute and State University
}

Submitted September 15, 2014 / Revised January 15, February 6, February 26, and March 2, 2015 /

Accepted March 2, 2015 / Published online March 17, 2015

Citation: Foust-Meyer, N., \& O’Rourke, M. E. (2015). High tunnels for local food systems: Subsidies, equity, and profitability. Journal of Agriculture, Food Systems, and Community Development, 5(2), 27-38. http://dx.doi.org/10.5304/jafscd.2015.052.015

Copyright (C) 2015 by New Leaf Associates, Inc.

\begin{abstract}
High tunnels are expanding opportunities to increase local food production in the midst of a globalized food system. They can overcome biophysical growing constraints by buffering temperatures to extend the growing season and shelter crops from extreme weather events. In 2010, the U.S. Department of Agriculture (USDA) Natural Resources Conservation Service (NRCS) began subsidizing the purchase of high tunnels. However, many questions remain about the factors influencing participation in the program and its impacts. Using mixed-methods research, this paper

a* Corresponding author: Nathaniel Foust-Meyer, Graduate Student, Department of Horticulture, Virginia Polytechnic Institute and State University; Saunders Hall, 490 West Campus Drive; Blacksburg, Virginia 24061 USA; +1- 434-9428919; nfmeyer@,vt.edu

b Megan E. O'Rourke Ph.D., Assistant Professor, Department of Horticulture, Virginia Polytechnic Institute and State University; Saunders Hall, 490 West Campus Drive; Blacksburg, Virginia 24061 USA.
\end{abstract}

assesses the biophysical, market, and sociodemographic factors influencing NRCS high tunnel adoption in the U.S. and examines how food production in high tunnels affects farmers, consumers, and the local food movement. Results show that the number of NRCS high tunnels per county increased in relation to a mixture of biophysical (high latitude, proximity to the coast, small average farm size, and high percent of farmland in vegetable production), market (high direct-to-consumer sales, good access to grocery stores, and high median household income), and socio-demographic (high percentage of nonwhite population, metropolitan counties with more than 250,000 people, and adjacent urban counties with fewer than 20,000 people) factors. According to our survey of Virginia high tunnel growers, high tunnel produce is largely sold locally (within 50 miles or $80 \mathrm{~km}$ of production) and marketed direct-to-consumers in Virginia. Many growers in Virginia who would not have purchased a high tunnel without NRCS support plan to purchase 
additional high tunnels in the future even without a subsidy. High tunnels are an emerging part of the U.S. local food movement, but work remains to ensure that their benefits reach all sectors of U.S. society.

\section{Keywords}

globalization, local food, season extension, Natural Resources Conservation Service (NRCS), Seasonal High Tunnel (SHT) initiative

\section{Introduction}

Food insecurity ${ }^{1}$ is on the rise globally (Khoury, Bjorkman, Dempewolf, Ramirez-Villegas, Guarino, Jarvis, Rieseberg, \& Struik, 2014). Many attribute this to volatility in global markets and food supply (Food and Agriculture Organization [FAO], 2008). Other criticisms of the globalized food system include increasingly homogeneous production and consumption patterns (Khoury et al., 2014; O’Hara \& Stagl, 2001), and negative impacts on personal health and quality of life (Kennedy, Nantel, \& Shetty, 2004). In the search for solutions, increasing local food ${ }^{2}$ production has been offered as one option to boost food security and combat the ill effects of globalization (Porter, Dyball, Dumaresq, Deutsch, \& Matsuda, 2014).

In the United States, local food production and consumption is on the rise. From 1992 to 2007, direct-to-consumer sales grew from US $\$ 404$ million to US $\$ 1.2$ billion, growing twice as fast as total agricultural sales in the U.S. (Tropp, 2010). Local food's market share has since expanded to US $\$ 6.1$ billion in 2012, which is approximately $1.5 \%$ of total U.S. farm sales (Low et al., 2015). The amount of food that can be grown, marketed directly to consumers, and consumed locally is often limited by market capacity and biophysical growing constraints (Martinez et al., 2010;

\footnotetext{
1 "Food security exists when all people, at all times, have physical and economic access to sufficient safe and nutritious food that meets their dietary needs and food preferences for an active and healthy life" (FAO, 2008).

${ }^{2}$ Local food as defined by the U.S. Congress in the 2008 Food, Conservation, and Energy Act is any regionally or locally agricultural product produced within less than 400 miles $(644 \mathrm{~km})$ from its origin, or within the State in which it is produced (Martinez, 2010).
}

Timmons, Wang, \& Lass, 2008). High tunnels are emerging as a technology that can increase local food production by protecting crops from cold temperatures and extreme weather events (Hood, Little, Coatney, \& Morgan 2011; O'Connell, Rivard, Harlow, Peet, \& Louws, 2012).

While there are a variety of high tunnel designs, most share several common attributes. They are covered by clear plastic, passively heated by solar energy, and built directly over the soil (Lamont, McGann, Orzolek, Mbugua, Dye, \& Reese, 2002). One high tunnel typically covers an area of around 2,000 square feet (186 square meters) (University of Illinois Extension [UIE], 2014). The cost of construction is roughly US $\$ 2$ per foot ${ }^{2}\left(0.1 \mathrm{~m}^{2}\right)$ (Coolong, 2012), which is much less than constructing a conventional greenhouse (Hood et al., 2011; Ochterski, 2012). They are predominately used to produce high-value and specialty produce (Cheng \& Uva, 2008; Winter, 2008). One standard high tunnel $(30 \mathrm{x} 70 \mathrm{ft}$. or $9 \mathrm{x}$ $21 \mathrm{~m}$ ) with 195 slicer tomato plants could net as much as US $\$ 5,200$ in a single growing season (Chase, 2012). This equates to approximately US $\$ 100,000$ per acre, ${ }^{3}$ compared to netting US $\$ 20,000$ per acre per year for high-value vegetables grown in the field (Chase, 2012).

The affordability of high tunnels and their potential to extend the growing season have made them profitable for a growing number of farmers (Carey, Jett, Lamont, Nennich, Orzolek, \& Williams, 2009; National Center for Appropriate Technology, 2009). Survey data collected at three farmers markets in Michigan showed that customers were willing to pay premium prices for salad greens, spinach, and tomatoes late and early in the year (Conner, Montri, Montri, \& Hamm, 2009). Forty-nine percent of the respondents indicated that they would pay up to US $\$ 3.00$ extra per head of lettuce in the winter months (Conner et al., 2009). Additionally, growers report that high tunnels help them to retain their customer base because they have produce to sell more consistently throughout the year (Arnold \& Arnold, 2003).

\footnotetext{
${ }^{3} 1$ acre $=0.4$ hectare
} 


\section{High Tunnels and the NRCS}

In response to the growing demand for local foods, the USDA instituted the Know Your Farmer, Know Your Food initiative to increase the connection between all levels of agricultural production and the consumer (USDA, 2013). In support of this initiative, the USDA tasked the Natural Resources Conservation Service (NRCS) with administering the Seasonal High Tunnel (SHT) initiative in 2009 (referred to throughout this paper as the NRCS high tunnel program), under the umbrella of the Environmental Quality Incentives Program (EQIP). In 2011, USDA then-deputy secretary Kathleen Merrigan made a statement attempting to directly link the NRCS high tunnel program with benefits to the local food system:

By capturing solar energy, seasonal high tunnels create favorable conditions enabling farmers to grow vegetables, berries, and other specialty crops in climates and at times of the year in which it would not be possible otherwise. Farmers who sell their high tunnel produce locally benefit from the extra income and the community benefits from the availability of fresh, locally grown food. (Merrigan, 2010)

The NRCS also stated a goal of serving historically underserved groups of farmers, including beginning (those operating their current farm for less than two years) (USDA NASS, 2014), and non-white farmers (USDA NRCS, 2014).

Under the NRCS high tunnel program, individual farms have been eligible to receive up to US $\$ 4,116$ toward the construction of a 2,178 square foot $\left(202 \mathrm{~m}^{2}\right)$ or smaller high tunnel (USDA NRCS, n.d.). After four years of government support in the U.S., it is time to examine the factors driving NRCS high tunnel adoption and to explore their impacts. Specifically, this paper will address the following questions:

(1) Where have NRCS high tunnels been built?

(2) What influence do biophysical, market, and socio-demographic factors have on NRCS high tunnel adoption and distribution?

\section{(3) Are high tunnels helping farmers, consumers, and/or the local food movement?}

\section{Methods}

To address our research questions, we employed mixed-methods research strategies. These included geographic information system (GIS) mapping and statistical analysis of the nationwide distribution by county of NRCS high tunnels in relation to countylevel biophysical, market, and socio-demographic factors. We also surveyed a subsample of high tunnel growers in Virginia to better understand how some farmers use high tunnels, and whether they are satisfied with the NRCS high tunnel program.

\section{GIS High Tunnel Mapping}

High tunnels funded by the NRCS from January 2010 through December of 2013 were mapped to show their distribution throughout the U.S. Data about NRCS high tunnels were obtained through a Freedom of Information Act request. High tunnel population data were totaledand mapped using ArcMap 10.1. To estimate total growing space covered by NRCS high tunnels, each high tunnel was assumed to be $2,000 \mathrm{ft}^{2}\left(186 \mathrm{~m}^{2}\right)$ (UIE, 2014).

\section{Regression Analysis}

A generalized linear model was constructed to examine relationships between county-level biophysical, socio-demographic, and market variables and the total number of NRCS high tunnels adopted per county in the U.S. until December 2013. The analysis used a negative binomial regression (O'Hara \& Pirog, 2013) to account for non-normal and overdispersed data. All statistical calculations were executed using $\mathrm{R}$ 3.0.2 (R Development Core Team, 2010).

The biophysical variables that were examined included latitude (U.S. Census Bureau, 2014), location outside the arid Midwest, average farm size (in acres) (USDA NASS, 2014), and vegetable production acreage (USDA NASS, 2014). Each was analyzed to describe a county's location and agricultural growing conditions (Wielgolaski \& Inouye, 2003). States considered as "arid Midwest" (Arizona, Colorado, Idaho, Kansas, Montana, 
Nebraska, Nevada, New Mexico, North Dakota, Oklahoma, South Dakota, Texas, Utah, and Wyoming) were coded as 0 , and all other states were coded as 1 . Vegetable production acres per county (USDA ERS, 2014) were divided by the total farm land per county prior to analysis (USDA NASS, 2014).

The market variables analyzed were indicators of the strength of the food system before the advent of the NRCS high tunnel program. The specific, local food system factors examined were the percent of direct-to-consumer sales compared to total agricultural sales in 2007 (USDA ERS, 2014), the number of farmers markets per thousand people in 2009 (USDA ERS, 2014), and the percent of farms with community supported agriculture (CSA) programs in 2007 (USDA ERS, 2014). Direct-to-consumer sales include the total agricultural sales directly to individuals via farm stands, farmers markets, CSAs, or pick-your-own operations (USDA ERS, 2014; Low and Vogel, 2011). Median household income in 2010 was used in the analysis as an indicator of consumer buying power, and the percentage of people with low access to food in 2010 (USDA ERS, 2014) was included as an indicator of food insecurity. According to the USDA definition, households within one mile $(1.6 \mathrm{~km})$ of a grocery store have good access to food in urban areas; in rural areas, that distance is increased to 20 miles $(32 \mathrm{~km})$ (USDA ERS, 2014).

The socio-demographic factors analyzed included characteristics of county and farmer populations. Specific characteristics of the county populations examined were the percentage of the total population composed of minority individuals (U.S. Census Bureau, 2014), urbanization as measured by the Rural Urban Continuum Code (RUCC), and the percentage of the population voting for the Democratic candidate in the 2012 presidential election (U.S. Geological Survey, n.d.). Specific characteristics of the farmer populations included the percentage of non-white (USDA NASS, 2014) and beginning farmers (USDA NASS, 2014). RUCC values range from one to nine and were developed by USDA to characterize counties by their degree of urbanization and proximity to metropolitan centers (USDA ERS,
2013). Counties with an RUCC value of 3 (i.e., metropolitan counties with fewer than 250,000 people) or 4 (i.e., nonmetropolitan counties with an urban population of 20,000 or more, and adjacent to a metropolitan area) were coded as 1 , and all other counties were coded as 0 .

\section{Farmer Survey}

High tunnel growers in Virginia were surveyed to elicit details about their demographics, production practices, sales venues, revenue, and satisfaction with the NRCS high tunnel program. Our survey contained 13 questions and was distributed using email lists via Virginia Cooperative Extension, the Virginia Association for Biological Farming, the Catawaba Sustainability Center (Catawaba, Virginia), and the Local Food Hub (Charlottesville, Virginia). Responses were collected by VT Survey (survey.vt.edu), facilitated by Virginia Tech. After receiving approval from the Institutional Review Board at Virginia Tech (IRB \#10-1377), an email soliciting survey participation was distributed in April 2014 and was followed by a second email solicitation two months later. Survey responses may have been suppressed due to the Internetbased survey collection method (from those who do not have Internet access) or due to farmers' lack of affiliation with the survey distribution outlets specified above.

\section{Results}

\section{GIS High Tunnel Mapping}

Between January 2010 and December 2013, the NRCS high tunnel program (USDA, 2013) provided cost-share to qualifying growers for the construction of 9,489 high tunnels. Under the program, 1,810 high tunnels were contracted in $2010,1,638$ in 2011, 3,043 in 2012, and 2,998 in 2013. Assuming an average size of $2,000 \mathrm{ft}^{2}(186$ $\mathrm{m}^{2}$ ) per high tunnel (UIE, 2014), these high tunnels cover roughly 436 acres (176 ha) $(0.027 \%$ of total harvested vegetable acreage in the U.S.) (USDA NASS, 2014). The states that adopted the most NRCS high tunnels were Alaska (513), Missouri (480), and Michigan (408); the states that adopted the least were Nevada (5), Arizona (22), and Wyoming (31). Mapping shows that NRCS high 


\section{Figure 1. Number of USDA Natural Resources Conservation Service (NRCS) High Tunnels in the U.S.} Funded January 2010-December 2013, by County

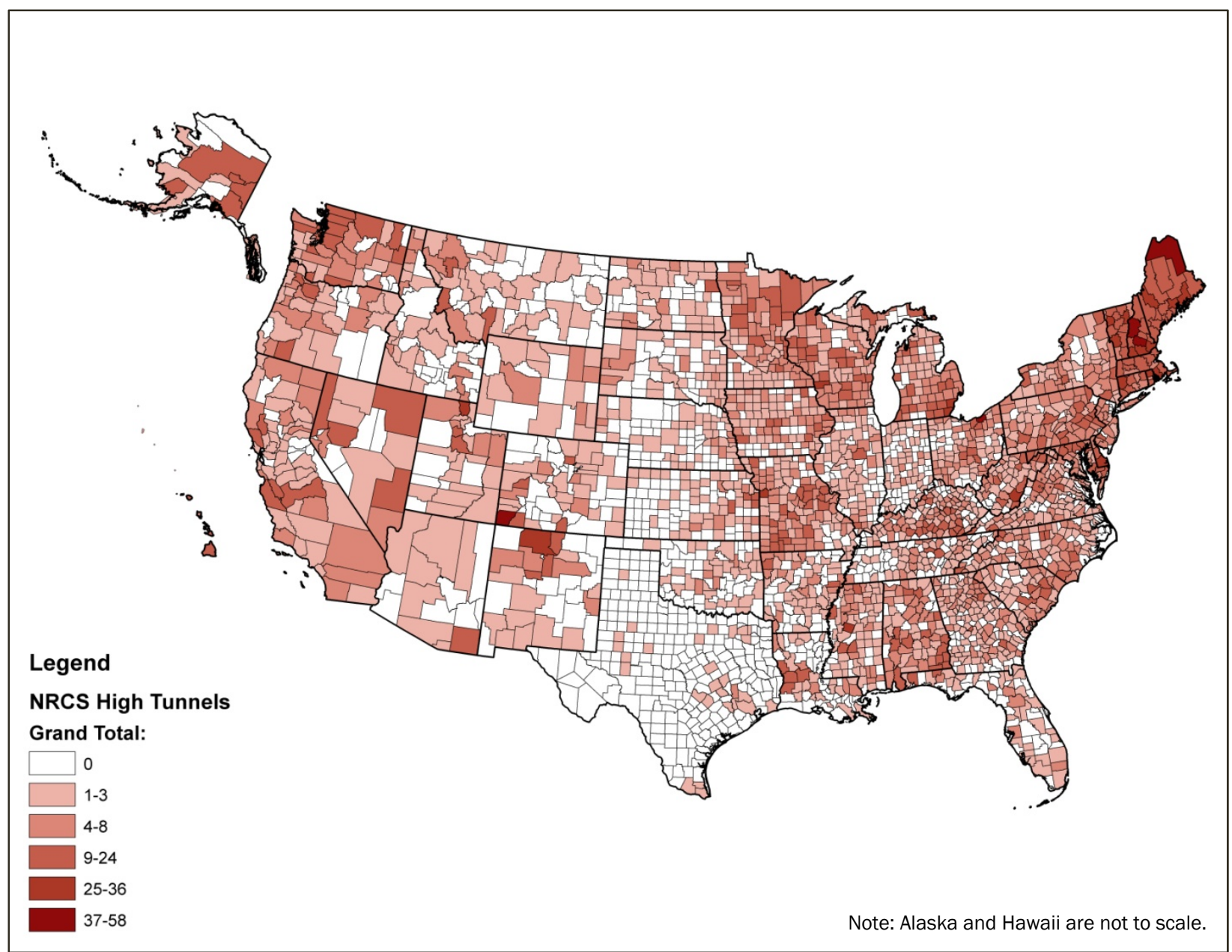

tunnels are not uniformly distributed throughout the U.S. (Figure 1).

\section{Regression Analysis}

Biophysical factors showed the strongest relationship with NRCS high tunnel adoption compared to market and socio-demographic factors (Table 1). Latitude was the strongest predictor of NRCS high tunnel adoption in the U.S.; counties at higher latitudes adopted more NRCS high tunnels than counties at lower latitudes. States outside the arid Midwest were more likely to adopt NRCS high tunnels than states inside it. Average farm size was negatively correlated with the number of NRCS high tunnels per county, meaning that NRCS high tunnels are more abundant in counties with a higher proportion of small farms. Additionally,
NRCS high tunnel numbers increased with increasing amounts of land used for field vegetable production (Table 1).

Market variables also influenced NRCS high tunnel adoption. As the median household income increased in a county, so did the number of NRCS high tunnels (Table 1). Furthermore, NRCS high tunnel adoption occurred where there were already relatively robust food systems. Where there was good access to grocery stores, NRCS high tunnel adoption was high (USDA ERS, 2014). Where direct-to-consumer sales were high in 2007, NRCS high tunnel adoption was also high. However, farmers markets and CSAs per county were not specifically related, individually, to NRCS high tunnel adoption.

Two significant relationships were found 
Table 1. Relationships Between USDA Natural Resources Conservation Service (NRCS) High Tunnel Adoption and Biophysical, Market, and Socio-demographic Variables

\begin{tabular}{|c|c|c|c|}
\hline & Variable & Estimate & $p$-value ${ }^{a}$ \\
\hline \multirow{4}{*}{ Biophysical } & Latitude $^{b}$ & $9.06 e-02$ & $<0.0001$ \\
\hline & Outside the arid Midwest ${ }^{c}$ & $5.61 \mathrm{e}-01$ & $<0.0001$ \\
\hline & Average farm size (acres) $(2007)^{d}$ & $-1.24 \mathrm{e}-04$ & $<0.0001$ \\
\hline & Vegetable production (acres) $^{\mathrm{d}}$ & $7.80 \mathrm{e}-05$ & $<0.01$ \\
\hline \multirow{5}{*}{ Market } & Direct-to-consumer sales (\%) $(2007)^{\mathrm{e}}$ & $4.33 e-02$ & $<0.0001$ \\
\hline & Median household income (2010)e & $4.60 \mathrm{e}-06$ & $<0.01$ \\
\hline & Food access (\% of total population) (2010)e & $2.86 \mathrm{e}-03$ & $<0.01$ \\
\hline & CSAs (\% of total farms) $(2007)^{\mathrm{e}}$ & $5.17 e-01$ & 0.09 \\
\hline & Farmers markets (\# per 1,000 people) $(2009)^{\mathrm{e}}$ & $1.26 \mathrm{e}-01$ & 0.74 \\
\hline \multirow{5}{*}{ Socio-demographic } & Non-white population (\%) $(2010)^{\mathrm{b}}$ & $4.14 \mathrm{e}-03$ & $<0.0001$ \\
\hline & $\operatorname{RUCC}^{f, g}$ & $1.77 e-01$ & $<0.001$ \\
\hline & Democratic votes (\%) $(2012)^{\mathrm{h}}$ & $2.17 \mathrm{e}-03$ & 0.21 \\
\hline & Non-white farmers (\%) (2007) d & $-1.33 e-03$ & 0.32 \\
\hline & Beginning farmers (\%) (2007) & $-2.81 e+00$ & 0.19 \\
\hline
\end{tabular}

a $p$-values $\leq 0.01$ are considered significant.

b U.S. Census Bureau, 2014

c States were assigned the following codes:

O. Arid Midwest: AZ, CO, ID, KS, MT, NB, NV, NM, ND, OK, SD, TX, UT, WY

1. Outside arid Midwest: All other states

d USDA, 2009; e USDA ERS, 2014; f USDA ERS, 2013

g Rural Urban Continuum Codes (RUCC) (USDA, ERS, 2013). Counties with a RUCC of 3 or 4 were aggregated and coded as 1 . All other counties were coded as 0 .

h U.S. Geological Survey, n.d.

between NRCS high tunnels and the socio-demographic factors examined (Table 1). A growing non-white population in a county was related to increased NRCS high tunnel adoption. Additionally, more high tunnels were adopted in small metropolitan counties (population fewer than 250,000 people) or large urban counties (population greater than 50,000 people) than in other places. There was no significant correlation between NRCS high tunnel adoption and Democratic votes in the 2012 presidential election. Furthermore, there was no significant relationship between NRCS high tunnels per county and the percentage of non-white or beginning farmers (Table 1).

\section{Farmer Survey}

Sixty-five Virginia high tunnel growers participated in our survey, which included both farmers who $\operatorname{did}(n=47)$ and did not $(n=18)$ participate in the NRCS high tunnel program. All together, these farmers managed 142 high tunnels (47 NRCS and 95 other high tunnels). While the total number of high tunnel producers in Virginia is unknown, our survey captured $15 \%$ of Virginia's 314 NRCS high tunnel recipients.

The surveyed high tunnel farmers answered questions about their demographics, growing practices, and sales venues, with results presented in Table 2. Survey participants reported their race as white $(92 \%)$, black $(3 \%)$, Hispanic $(2 \%)$, or did not disclose their race $(3 \%)$. The gender of participants was $41 \%$ female, $56 \%$ male, and $3 \%$ undisclosed. Forty-six percent of respondents reported using their high tunnel(s) for year-round production, and 54\% use them throughout spring, summer, and fall. Respondents reported growing a wide variety of produce in their high tunnels; all grew vegetables, fruit, or both, and 65\% also grew herbs and/or cut flowers. Survey responses strongly support the presumption that NRCS high 
Table 2. Virginia High Tunnel Growers Survey ( $n=65$, except where noted)

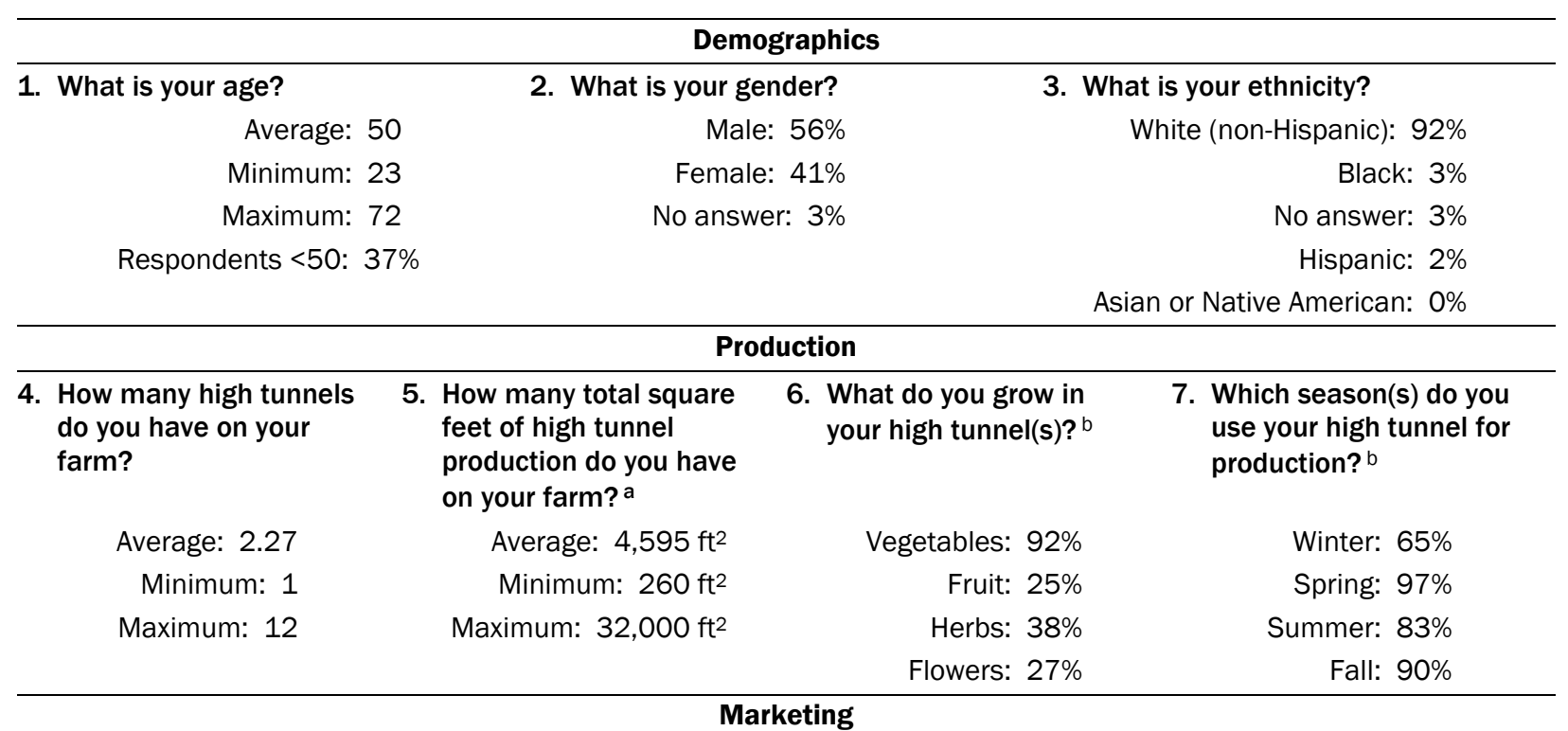

\begin{tabular}{|c|c|c|}
\hline $\begin{array}{l}\text { 8. How many miles from your farm to } \\
\text { the market(s) is } 75 \% \text { or more of } \\
\text { your high tunnel produce sold? }{ }^{c}\end{array}$ & $\begin{array}{l}\text { 9. Please indicate your marketing } \\
\text { strategy(s). }{ }^{b}\end{array}$ & $\begin{array}{l}\text { 10. Please indicate the type(s) of direct } \\
\text { market venues you use. }{ }^{b}\end{array}$ \\
\hline 50 miles or less: $82 \%$ & Direct-to-consumer/ & Farmers market: $71 \%$ \\
\hline 51 to 100 miles: $13 \%$ & restaurant/food hub: $100 \%$ & Direct-to-restaurant: $38 \%$ \\
\hline 101 to 150 miles: $3 \%$ & Wholesale: $14 \%$ & CSA: $32 \%$ \\
\hline 151 to 200 miles: $0 \%$ & & Roadside stand: $24 \%$ \\
\hline \multirow[t]{3}{*}{ More than 201 miles: 2\% } & & On-farm stand: $20 \%$ \\
\hline & & Pick-your-own: 8\% \\
\hline & & Other: $4 \%$ \\
\hline \multicolumn{3}{|c|}{ Economics } \\
\hline $\begin{array}{l}\text { 11. Please select the range that best } \\
\text { describes your annual revenue per } \\
\text { high tunnel. }(n=21 \text {; all in US } \$) .^{d}\end{array}$ & $\begin{array}{l}\text { 12. Would you have constructed a high } \\
\text { tunnel without NRCS funding? } \\
(n=44)\end{array}$ & $\begin{array}{l}\text { 13. If you participated in the NRCS high } \\
\text { tunnel program, please rank how } \\
\text { likely you are to purchase a future } \\
\text { high tunnel without NRCS funding. } \\
(n=47)\end{array}$ \\
\hline$\$ 0$ to $500: 14 \%$ & No: $66 \%$ & Not likely: $15 \%$ \\
\hline$\$ 501$ to $\$ 2,000: 33 \%$ & Yes: $34 \%$ & Less than likely: $6 \%$ \\
\hline$\$ 2,001$ to $\$ 3,000: 19 \%$ & & Undecided: $24 \%$ \\
\hline >\$3,000: $10 \%$ & & Likely: $23 \%$ \\
\hline I do not know: $24 \%$ & & Very likely: $32 \%$ \\
\hline
\end{tabular}

a $1 \mathrm{ft}^{2}=0.09 \mathrm{~m}^{2}$

b Respondents could select multiple options.

c 1 mile $=1.6 \mathrm{~km}$

d Excludes data from respondents who did not participate in the NRCS high tunnel program and who had more than 1 high tunnel.

tunnels contribute to local food availability. Of the 65 respondents, $82 \%$ sold the majority of their product (at least $75 \%$ ) within 50 miles $(80 \mathrm{~km}$ ) of their farm. All respondents also reported selling through direct-to-consumer venues, with farmers markets being the most popular venue.

The NRCS high tunnel program increased the willingness of farmers in Virginia to purchase future high tunnels. Forty-four percent of NRCS high tunnel recipients would, and 66\% would not, 
have built their NRCS high tunnel without the cost-share program. After using the NRCS high tunnel, $56 \%$ of survey respondents indicated that they are likely or very likely to purchase another high tunnel without a subsidy, while only $21 \%$ were not likely. Twenty-three percent of survey participants were undecided about purchasing a future high tunnel. All the farmers who reported generating more than US $\$ 2,000$ per high tunnel per year of revenue were likely or very likely to purchase a future high tunnel without government support.

\section{Discussion}

\section{Farmers}

The strongest determining factors in the distribution of NRCS high tunnels are biophysical (Table 1). Not surprisingly, farmers at high latitudes are taking advantage of high tunnels because they can extend the growing season in cold climates (Figure 1; Smeenk \& Nakazawa, 2011). Farmers outside of the arid Midwest also adopted high tunnels at higher rates than in landlocked states with hot, dry climates. Most farms in the arid Midwest are large, distant from metropolitan areas, and have little existing vegetable production. These factors are all significantly related to high tunnel adoption, according to our analysis (Table 1) (Low \& Vogel, 2011).

High tunnels may present an opportunity for small-scale vegetable farmers (less than US $\$ 10,000$ annual revenue) to grow their operations (Table 1). While globalization of the food system tends to favor large-scale operations (Jensen, 2010), many large farms depend on uniformity in management. High tunnels, on the other hand, require more nuanced management and labor that cannot be performed mechanically, and therefore may be better suited to use on small farms (Biernbaum, 2013). Furthermore, many small farms suffer from a lack of credit and an erratic flow of income (Dodson \& Koenig, 1995). Our survey results show that farmers in Virginia are using high tunnels to extend their growing season, year-round in some places, which can increase total sales and stabilize income throughout the year (Table 2). As a bonus, high tunnel growers are also likely to receive premium prices for out-of-season, local produce (Arnold \& Arnold, 2003; Lamont et al., 2002; Orzolek, 2013).

The NRCS high tunnel program was intended to benefit historically underserved farm operators (USDA NRCS, 2014; National Sustainable Agriculture Coalition [NSAC], 2014). Table 1 indicates that adoption of NRCS high tunnels is positively related to the percentage of the population that is non-white. However, there is no correlation between the percentage of non-white farmers or beginning farmers and the presence of NRCS high tunnels in a given county. On the other hand, analyses by NSAC show that underserved, and particularly beginning farmers, have enrolled in the NRCS high tunnel program at higher rates than nonunderserved farmers (NSAC, 2014). Indeed, more than $70 \%$ of NRCS high tunnel contracts were awarded to historically underserved operators in 2013 (NSAC, 2014). While the NSAC analysis examined only data about NRCS high tunnel recipients, our data describe the underserved farmer populations of entire counties. Therefore, our data indicate that counties with high proportions of underserved farmers were not more successful than counties traditionally well-served by the USDA in obtaining NRCS high tunnel contracts.

Our survey conducted with farmers in Virginia indicates that high tunnels may particularly benefit female farmers (Table 2), which is encouraging in a traditionally male-dominated global food system (Trauger, 2004). When asked to identify their gender, $41 \%$ of surveyed high tunnel growers $(n=65)$ identified as female principal operators. This is in contrast to national averages reporting females are principal operators of only $14 \%$ of all farms, $12 \%$ of vegetable farms, and $17 \%$ of small farms (USDA NASS, 2014). Most female farmers can be found in the west and northeast (USDA NASS, 2010), which is also where many of the NRCS high tunnels are located (Figure 1).

\section{Consumers}

This research highlights the possibility that consumers who lack access to grocery stores and are low-income may not be benefitting from the additional produce grown in NRCS high tunnels (see Table 1) (Colasanti, Conner, \& Smalley, 2010; Hill, Wishaw, \& Hargrove, 2013). In Virginia the survey 
responses indicate that high tunnels contribute more to local than to global markets. Our national data further indicate that NRCS high tunnel adoption increased in or near small metropolitan counties with high incomes and easy access to grocery stores (Table 1). Therefore we can conclude that NRCS high tunnels may be doing little to alleviate food deserts or to provide fresh, locally grown food to low income-communities. In fact, they may be contributing to a problem with the local food system that many people criticize, namely, that it primarily serves upper-income, urban communities (Alkon \& McCullen, 2011; Campbell, CarlisleCummins, \& Feenstra, 2013; Johnston \& Baker, 2005).

\section{Local Food Movement}

There may be a positive feedback between a strong local food market, the adoption of high tunnels, and the continued growth of that market (Sundkvist, Milestad, \& Jansson, 2005). Our data show that direct-to-consumer sales in 2007 were highly correlated with consequent adoption of NRCS high tunnels (Table 1). In Virginia, high tunnel produce was sold primarily within 100 miles (161 $\mathrm{km}$ ) of where it was grown. This is well within the limits of USDA's definition of local (400 miles, or $644 \mathrm{~km}$ ) (Martinez et al., 2010). The adoption of new technologies does not occur in a vacuum (Adler, Fung, Huber, \& Young, 2003). Farmers looking to enter local food markets may be finding success selling their high tunnel produce where the local food market is already strong.

High tunnels appear to be an emerging technology that will continue to contribute to the local food movement (Martinez et al., 2010). Our survey of Virginia farmers indicates that farmers find high tunnel technology profitable and are willing to purchase new high tunnels even without further government subsidies. Growing food in high tunnels is much more common in other countries, such as China, Spain, Japan, and Italy (Lamont, 2009). In 2007, before the advent of the NRCS high tunnel program, Carey et al. (2009) estimated that there were only 5,000 acres (2,023 ha) of high tunnel production in the U.S. $(0.01 \%$ of total vegetable production acreage). Reasons for relatively low use of high tunnels and other protected production methods in the U.S. could include low transportation costs and highly centralized marketing systems. These tend to favor large-scale farms that supply cheap, but potentially lower quality, produce than food produced locally (Edwards-Jones et al., 2008).

\section{Conclusions}

High tunnels are a promising technology that can increase farmers' profits (Arnold \& Arnold, 2003; Chase, 2012), supply fresh and healthy produce to consumers, and fuel growth in the local food movement (ATTRA, 2009). They can also fill a niche for out-of-season local foods that is unlikely to be filled by large-scale producers growing for the global food system (Biernbaum, 2013). As with many newly adopted technologies, high tunnels may be a double-edged sword. While many hope that they will equitably increase local food supplies and food security, our data show that the NRCS high tunnel program was not particularly successful in counties with low incomes or large, underserved farmer populations. Furthermore, those counties that already had diverse food choices now have even more choices because of U.S. government support. Future research efforts should continue to investigate the impacts of high tunnels on food deserts, poor communities, and underserved farm operators.

\section{References}

Adler, S., Fung, S., Huber, G., \& Young, L. (2003). Learning our way towards a sustainable agri-food system: Three cases from Sweden: Stockholm Farmers Market, Ramsjö Community Supported Agriculture and Järna Initiative for Local Production (Ecological Agriculture Report No. 38). Uppsala, Sweden: Centre for Sustainable Agriculture, Swedish University of Agricultural Sciences. Retrieved from http://www.slu.se/Documents/externwebben/ centrumbildningar-projekt/epok/Publikationer/ ekolantbruk38.pdf

Alkon, A. H., \& McCullen, C. G. (2011). Whiteness and farmers markets: Performances, perpetuations ... contestations? Antipode, 43(4), 937-959. http://dx.doi.org/10.1111/j.14678330.2010.00818.x 
Arnold, P., \& Arnold, S. (2003). The early birds get the returns. Rodale Institute. Retrieved from http://www.newfarm.org/features/0503/arnolds grow.shtml

Biernbaum, J. (2013). Water, soil and fertility management in organic high tunnels. Retrieved from Michigan State University Department of Horticulture website: http://www.hrt.msu.edu/assets/PagePDFs/johnbiernbaum/HighTunnelWaterSoilFertility201310pgs.pdf

Campbell, D. C., Carlisle-Cummins, I., \& Feenstra, G. (2013). Community food systems: Strengthening the research-to-practice continuum. Journal of Agriculture, Food Systems, and Community Development, 3(3), 121-138. http://dx.doi.org/10.5304/jafscd.2013.033.008

Carey, E. E., Jett, L., Lamont, Jr., W. J., Nennich, T. T., Orzolek, M. D., \& Williams, K. A. (2009).

Horticultural crop production in high tunnels in the United States: A snapshot. HortTechnology, 19(1), 37-43. Retrieved from http://horttech.ashspublications.org/content/19/1 37.full.pdf

Chase, C. (2012). Selected alternative agricultural financial benchmarks. Iowa State University Extension and Outreach. Retrieved from http://www.extension. iastate.edu/agdm/wholefarm/html/c3-65.html

Cheng, M.-L., \& Uva, W.-F. (2008). Removing barriers to increase high tunnel production of horticultural commodities in New York: Economic and marketing study final report. Retrieved from the Cornell University Department of Applied Economics and Management website: http://www.hort.cornell.edu/hightunnel/about/ research/economics/removing_barriers_uva_ cheng.pdf

Colasanti, K. J. A., Conner, D. S., \& Smalley, S. B. (2010). Understanding barriers to farmers' market patronage in Michigan: Perspectives from marginalized populations. Journal of Hunger \& Environmental Nutrition, 5(3), 316-338. http://dx.doi.org/10.1080/19320248.2010.504097

Conner, D. S., Montri, A. D., Montri, D. N., \& Hamm, M. W. (2009). Consumer demand for local produce at extended season farmers' markets: guiding farmer marketing strategies. Renewable Agriculture and Food Systems, 24(4), 251-259. http://dx.doi.org/10.1017/S1742170509990044

Coolong, T. (2012). Low cost high tunnel construction.

Retrieved from the eXtension website: http://www.extension.org/pages/18356/low-costhigh-tunnel-construction\#.VBXWi mwLz0
Dodson, C., \& Koenig, S. (1995). Young commercial farmers: Their financial structure and credit sources. USDA Economic Research Service. Agricultural Income and Finance Situation Outlook Report, 56, 40-44.

Edwards-Jones, G., Milà i Canals, L., Hounsome, N., Truninger, M., Koerber, G., Hounsome, B.,... Jones, D. L. (2008). Testing the assertion that 'local food is best': The challenges of an evidence-based approach. Trends in Food Science \& Technology, 19(5), 265-274.

http://dx.doi.org/10.1016/j.tifs.2008.01.008

Food and Agriculture Organization (FAO) of the United Nations. (2008). The state of food insecurity in the world 2008. Rome: United Nations. Retrieved from http://www.fao.org/docrep/011/i0291e/ i0291e00.htm

Hill, W. A., Wishaw, J., \& Hargrove, T. M. (2013). Socially disadvantaged farmer issues can be addressed when diverse frontline agricultural workers proactively work together. Professional Agricultural Workers Journal, 1(1), Article 3. http://tuspubs.tuskegee.edu/pawj/vol1/iss1/3

Hood, K., Little, R., Coatney, K., \& Morgan, K. L. (2011, October). Exploring the potential for increasing revenues of small farms in Mississippi: Utilizing high tunnel technology for market season extension. Poster session presented at the 2011 Food Distribution Research Society Annual Conference, Portland, Oregon.

Jensen, J. (2010). Local and regional food systems for rural futures (RUPRI Rural Futures Lab Foundation Paper No. 1). Retrieved from the Rural Policy Research Institute, Rural Futures Lab website: http://www.rupri.org/Forms/RUPRI RuralFutures-Lab 2010 Food Systems for Rural Futures.pdf

Johnston, J., \& Baker, L. (2005). Eating outside the box: FoodShare's good food box and the challenge of scale. Agriculture and Human V alues, 22(3), 313-325. http://dx.doi.org/10.1007/s10460-005-6048-y

Kennedy, G., Nantel, G., \& Shetty, P. (2004). Globalization of food systems in developing countries: A synthesis of county case studies. In FAO (Ed.), Globalization of food systems in developing countries: Impact on food security and nutrition (FAO Food and Nutrition Paper No. 83) (pp. 1-25). Rome: FAO. Retrieved from http://www.fao.org/3/a-y5736e/ 
Khoury, C. K., Bjorkman, A. D., Dempewolf, H., Ramirez-Villegas, J., Guarino, L., Jarvis, A., Rieseberg, L. H., \& Struik, P. C. (2014). Increasing homogeneity in global food supplies and the implications for food security. Proceedings of the National Academy of Sciences, 111(11), 4001-4006. http://dx.doi.org/10.1073/pnas.1313490111

Lamont, Jr., W. J. (2009). Overview of the use of high tunnels worldwide. Hort Technology, 19(1), 25-29. Retrieved from http://horttech.ashspublications. org/content/19/1/25.full

Lamont, Jr., W. J., McGann, M. R., Orzolek, M. D., Mbugua, N., Dye, B., \& Reese, D. (2002). Design and construction of the Penn State high tunnel. HortTechnology, 12(3), 447-453. http://horttech.ashs publications.org/content/12/3/447.full.pdf + html

Low, S. A., Adalja, A., Beaulieu, E., Key, N., Martinez, S., Melton, A., Perez, A., Ralston, K., Stewart, H., Suttles, S., Vogel, S., \& Jablonski, B. B. R. (2015). Trends in U.S. local and regional food systems: $A$ report to Congress (Administrative Publication No. AP-068). Washington, D.C.: USDA, Economic Research Service. Retrieved from http://www.ers.usda.gov/ publications/ap-administrative-publication/ap$\underline{068 . a s p x}$

Low, S. A., \& Vogel, S. (2011). Direct and intermediated marketing of local foods in the United States (Economic Research Report No. ERR-128). Washington, D.C.: USDA, Economic Research Service. Retrieved from http://www.ers.usda.gov/publications/erreconomic-research-report/err128.aspx

Martinez, S., Hand, M. S., Da Pra, M., Pollack, S., Ralston, K., Smith, T., Vogel, S., Clark, S., Lohr, L., Low, S. A., \& Newman, C. (2010). Local food systems: Concepts, impacts, and issues (Economic Research Report No. ERR-97). Washington, D.C.: USDA, Economic Research Service. Retrieved from http://www.ers.usda.gov/publications/erreconomic-research-report/err97.aspx

Merrigan, K. (2010, December 6). High hopes for high tunnels [Web log post]. Retrieved from http://blogs.usda.gov/2010/12/06/high-hopesfor-high-tunnels-3/

National Center for Appropriate Technology (NCAT). (2009). Extending the growing season. ATTRAnews [Newsletter of the National Sustainable Agriculture Information Center (ATTRA)], 17(2), 1-4. https:// attra.ncat.org/newsletter/attranews 0509.html
National Sustainable Agriculture Coalition (NSAC). (2014, June 27). Seasonal high tunnels support conservation and new farmers [Web log post]. Retrieved from http://sustainableagriculture.net/ blog/high-tunnel-update/

O’Connell, S., Rivard, C., Harlow, C., Peet, M. M., \& Louws, F. (2012). High tunnel and field production of organic heirloom tomatoes: Yield, fruit quality, disease, and microclimate. HortScience, 47(9), 12831290.

O’Hara, J. K., \& Pirog, R. (2013). Economic impacts of local food systems: Future research priorities. Journal of Agriculture, Food Systems, and Community Development, 3(4), 35-42. http://dx.doi.org/10.5304/jafscd.2013.034.003

O'Hara, S. U., \& Stagl, S. (2001). Global food markets and their local alternatives: A socio-ecological economic perspective. Population and Environment, 22(6), 533-554. http://dx.doi.org/10.1023/A:1010795305097

Ochterski, J. (2012). Collaborative marketing for small farms: Selling and working together for profitability. Cornell University Cooperative Extension. Retrieved from http://smallfarms.cornell.edu/files/2012/05/Colla borative-Marketing-for-Small-Farms-10385vc.pdf

Orzolek, M. D. (2013). Increasing economic return to high tunnel with specialty crops. In M. D. Orzolek \& W. J. Lamont (Eds.), International Symposium on High Tunnel Horticultural Crop Production. ISHA Acta Horticulturae, 987. http://www.actahort.org/books/987/index.htm

Porter, J. R., Dyball, R., Dumaresq, D., Deutsch, L., \& Matsuda, H. (2014). Feeding capitals: Urban food security and self-provisioning in Canberra, Copenhagen and Tokyo. Global Food Security, 3(1), 1-7. http://dx.doi.org/10.1016/j.gfs.2013.09.001

Smeenk, J., \& Nakazawa, A. (2011). Hoop houses in rural Alaska (Bulletin HGA-00028). Fairbanks, Alaska: Cooperative Extension Service, University of Alaska Fairbanks. Retrieved from http://www.uaf. $\mathrm{edu} / \mathrm{ces} / \mathrm{pubs} / \mathrm{catalog} /$ detail $/$ index.xml?id $=459$

Sundkvist, A., Milestad, R., \& Jansson, A. (2005). On the importance of tightening feedback loops for sustainable development of food systems. Food Policy, 30(2), 224-239. http://dx.doi.org/10.1016/j.foodpol.2005.02.003 
Timmons, D., Wang, Q., \& Lass, D. (2008). Local foods: Estimating capacity. Journal of Extension, 46(5), 5FEA7. Retrieved from: http://www.joe.org/joe/2008october/a7.php

Trauger, A. (2004). 'Because they can do the work': Women farmers in sustainable agriculture in Pennsylvania, USA. Gender, Place \& Culture, 11(2), 289-307. http://dx.doi.org/10.1080/0966369042000218491

Tropp, D. (2010, March). What do we know about consumer demand for local food? Presentation to the Natural Products Expo West. Retrieved from the USDA Agricultural Marketing Service (AMS) website: http://www.ams.usda.gov/AMSv1.0/getfile? $\underline{\mathrm{dDocN} N a m e=S T E L P R D C 508369}$

University of Illinois Extension (UIE). (2014). Production and economics of high tunnel vegetables and strawberries. Local Food Systems \& Small Farms. http://web.extension.illinois.edu/smallfarm/factsh eets/fs1318.html

U.S. Census Bureau. (2014). 2014 U.S. Gazetteer files. Retrieved from http://www.census.gov/geo/mapsdata/data/gazetteer2014.html

U.S. Department of Agriculture (USDA). (2009). 2007 Census publications: Desktop data query tool 1.02. Retrieved from http://www.agcensus.usda.gov/Publications/ 2007/Online_Highlights/Desktop_Application/

USDA. (2013). Know Your Farmer, Know Your Food: Our mission. Retrieved from http://www.usda.gov/wps/ portal/usda/usdahome?navid=KYF MISSION

USDA, Economic Research Service (ERS). (2013). Rural
Urban Continuum Codes. Retrieved from http://www.ers.usda.gov/data-products/ruralurban-continuum-codes.aspx\#.VBcLnfldUrV

USDA, ERS. (2014). Food Environment Atlas. Retrieved from http://www.ers.usda.gov/data-products/ food-environment-atlas/data-access-anddocumentation-downloads.aspx\#.VA9aX_ldUrU

USDA, National Agriculture Statistics Service (NASS). (2014). Vegetables 2013 Summary. Retrieved from http://www.nass.usda.gov/Publications/Todays Reports/reports/vgan0314

USDA, Natural Resources Conservation Service (NRCS). (n.d.). Seasonal High Tunnel Initiative System for Crops. Retrieved from http://www.nrcs.usda. gov/wps/portal/nrcs/detailfull/national/programs $\angle$ ?cid=stelprdb1046250

USDA, NRCS. (2014). Opportunities for historically underserved clients. Retrieved from http://www.nrcs. usda.gov/wps/portal/nrcs/detail/or/home/?cid= nrcs142p2 044211

U.S. Geological Survey. (n.d.). Presidential election 2012 [PDF map]. Retrieved from http://nationalmap. gov/small scale/printable/elections.html\#list

Wielgolaski, F. E., \& Inouye, D. W. (2003). High latitude climates. In M. D. Schwartz (Ed.), Phenology: An integrative environmental science (pp. 175-194). The Netherlands: Springer.

Winter, M. (2008, September 5). Old Order farmers profit from new order idea. Cornell Chronicle. Retrieved from http://www.news.cornell.edu/stories/2008/ 09/old-order-farmers-profit-new-order-idea 